\title{
Rationale for Material Selection in Landscaping for Checking Intrusion in Public and Private Primary Schools in Nsukka Urban Area of Enugu State, Nigeria
}

\author{
Arinzechukwu Victor Okanya ${ }^{1}$, Deborah Ahuoiza Vincent ${ }^{2}$, Asogwa Japel Onyekachi ${ }^{3}$ \\ ${ }^{1}$ Department of Industrial Technical Education, Faculty of Vocational and Technical Education, \\ University of Nigeria, Nsukka, Enugu, Nigeria.Email: arinze.okanya@unn.edu.ng \\ ${ }^{2}$ Department of Industrial Technical Education, Faculty of Vocational and Technical Education, \\ University of Nigeria, Nsukka, Enugu, Nigeria.Email: deborah.vincent@unn.edu.ng \\ ${ }^{3}$ Department of Industrial Technical Education, Faculty of Vocational and Technical Education, \\ University of Nigeria, Nsukka,Enugu,Nigeria.Email: japel.asogwa@unn.edu.ng
}

\begin{tabular}{|c|c|}
\hline & \multirow{16}{*}{$\begin{array}{l}\text { Results: The findings revealed some rationale for material selection in } \\
\text { landscaping for checking intrusion in public and private primary schools } \\
\text { which includes; the durability, maintenance, aesthetic and cost of each } \\
\text { landscaping material; the initial and ongoing costs, the availability of the } \\
\text { material to be used and the life cycle assessment considerations such as } \\
\text { material performance, and impact on the environment and the ability to } \\
\text { reuse the material. } \\
\text { Practical Implications: The results of the study might be of interest to } \\
\text { school principals and builders. The study reflects the common perceptions } \\
\text { about landscaping to prevent intrusion into schools, and hence of practical } \\
\text { implications to concerned education authorities in Nsukka urban, Nigeria. } \\
\text { Originality/Value: The study identified the effects of poor landscaping in } \\
\text { public and private primary schools which include; exposure of schools to } \\
\text { risk of attacks, theft and exposure of schools to ecological problems such as } \\
\text { flooding, erosions, deep gullies and a degrading environment. }\end{array}$} \\
\hline Article history: & \\
\hline & \\
\hline Revised: & \\
\hline Accepted: 04 February 2021 & \\
\hline Keywo & \\
\hline Landscaping & \\
\hline & \\
\hline Materials for Landscaping, & \\
\hline Intrusion & \\
\hline Paper Type : & \\
\hline Research Article & \\
\hline Corresponding Author: & \\
\hline Deborah Ahuoiza Vincent & \\
\hline Email: & \\
\hline & \\
\hline
\end{tabular}

\section{Introduction}

Increasing population, cultural shift, immigration, and natural disasters bring up the need for housing and increased infrastructural development in schools. In today's changing urban 
areas, the schools are affected by dense housing and traffic. Students in public and private schools are then subjected to a great level of risks due to intrusion of thieves and other unguided elements into the school environment. Intrusion of these unguided elements in schools mostly results in the kidnapping of the students, physical assault/harassment and stealing of school/students properties by petty thieves. Ashworth, (2004) stated that thieves, bandits, and other unwanted element can intrude into the schooling environment due to poor landscaping of the school, poor choice of landscaping material and in most cases due to lack of landscaping of the school perimeter.

Landscape is the design of outdoor spaces with vegetation, water features, as well as landmarks and structures that help achieve healthy and sustainable environment to surround the human and provide them the best opportunity to adapt (Claudio eta 1., 2016). Landscaping according to Clamp and Lupton, (2007) is concerned with the arrangement of land, water, plant forms, and structures, for their best and greater enjoyment. It deals with land-planning problems such as building sites, gardens, outdoor-living areas, playgrounds, and parks. To meet the needs of man, most landscapes are usually subjected to human modification so as to utilize existing earth forms or to model new ones. During the modification process, consideration must be given to the soil, to drainage, grading of terraces, banks, and slopes, balancing and measuring, excavation and filling operations. These processes require a knowledge of design and construction that overlaps in the fields of architecture, engineering, horticulture, botany, and other branches of the arts and sciences (Brook, 2008). According to Kenaway (2016), landscape which is the design of outdoor areas, landmarks, and structures are meant to achieve better environmental and social-behaviour of students within the learning environment. He stated that the absence of school landscaping is a big fault, which affects the social and environmental behaviour of the students.

The single most important goal of planning a building site to resist terrorism and security threats is the protection of life, property, and operations and that of the public/private primary schools is not an exception. Schools as learning organization should generate encouraging learning environment for students to achieve academic behaviour and social skills. The school is a place where it forms a framework to teach, educate and bring up children (Dudeck, 2007). Schools, as a teach-learn organizations, should be carried out in a serene environment devoid of any form of external aggression or threat to peace operation that may pose threat to the peace. To establish a successful learning environment, the interior spaces as well as exterior environment should be well designed to raise the academic performance, boost social behaviour, increase self-confidence, creating healthier environment and enhance sense of belonging for students.

Kenaway (2016) stated that incidence of intrusion has led to loss of computers, air conditioners, generator sets, tables, chairs, lockers and other properties belonging to either the students or the school authorities in public/private primary schools. School landscape can play a significant role in providing safe, stimulating environments where students can study, explore, regardless of their educational needs without the fear of being attacked or losing 
their properties through theft. School landscaping should be practiced widely across the state to provide security to student's lives and properties within the school premises. Decisionmaking in support of this purpose should be based first and foremost on a comprehensive assessment of the manmade threats and hazards so that planning and design countermeasures are appropriate and effective in the reduction of vulnerability and risk (Ecalle, 2006). One can realize the importance of school landscaping by comparing school buildings that have been adequately landscaped with those in which the landscaping has been neglected. Such comparison will show that a poor arrangement of the landscape can greatly decrease the value of a well-designed building. Proper landscaping, on the other hand, can provide a beautiful setting for a school building. Landscaping can add to the comfort of the occupants by providing shade and windbreaks and by screening off undesirable views when suitable materials are used for landscaping.

Materials for Landscaping may come from a number of elements/materials so as to create a barrier which will reduce intrusion of unwanted elements into the school environment. To create a physical barrier, some come naturally while some are manmade. Natural barrier elements include rivers, lakes, waterways, steep terrain, mountains, barren areas, plants, and other terrain features that are difficult to traverse, while manmade elements include fencing, walls, buildings, bollards, planters, concrete barriers, and fountains. Selection of elements must consider the level of security desired and the type of threat most likely to occur (Brook, 2008) Fencing is a common means of establishing a physical protective barrier to protect schools. The type of fencing used depends primarily on the threat and the degree of permanence. It may also depend on the availability of materials and the time needed for construction. Fencing may be erected for other uses besides impeding personnel access, such as obstructing views, serving as a means to defeat stand-off weapon systems (e.g., rocket propelled grenades), and serving as a barrier to hand-thrown weapons (e.g., grenades and firebombs). Dudek (2000) stressed that it is important to recognize that fencing provides very little delay when it comes to motivated aggressors, but it can act as a psychological deterrent when an aggressor is deciding which building to attack. According to Kelkit and Ozel (2003), the commonly used fencing types includes; chain-link fence, anti-climb (CPTED) fence, barbed wire fence, barbed tape or concertina fence, triple-standard concertina wire fence, tangle-foot wire fence and cable fence.

A popular material for creating physical barrier in order to check intrusion to schools is brick or block masonry or cast-in-situ concrete walls. Clamp and Lupton (2007) suggested that school brick or block wall should be at least 7 feet high and should have a barbed wire top guard, depending on the threat and application. The windows, active doors, and other designated openings should be protected with fastening bars, grilles, or chain-link screens, and window barriers should be fastened from the inside. If hinged, the hinges and locks must be on the inside to facilitate emergency egress. Barrier walls designed to resist the effects of an explosion can, in some cases, act to reduce the pressure levels acting on the exterior walls of school buildings. Bollards are concrete filled steel pipes that can be placed every few feet along the curb of a sidewalk to prevent vehicle intrusion, (Brook, 2008). In order to resist the 
impact of a vehicle, the bollard are fully embedded into a concrete strip foundation that is several feet deep. The height of the bollard above ground are usually higher than the bumper of the vehicle, typically 39 to 40 inches. The spacing of the bollards is based on several factors, including the minimum width of a vehicle, and the number of bollards required to withstand the impact. As a rule of thumb, the centre to centre spacing should be between 3 and 5 feet to be effective. The foundation should be designed according to site soil conditions. An alternative to a bollard is a plinth wall, which is a continuous low wall constructed of reinforced concrete with a buried foundation. The bollard or plinth wall is designed by equating the kinetic energy of the vehicle at impact with the strain energy absorbed by the barrier and the vehicle. Parking restrictions can help to keep potential threats away from school buildings. In urban settings, however, curb side or underground parking is often necessary and sometimes difficult to control. Mitigating the risks associated with parking requires creative design measures, including parking restrictions, perimeter buffer zones, barriers, structural hardening, and other architectural and engineering solutions (Clamp \& Lupton, 2007). Operational measures may also be necessary to inspect or screen vehicles entering parking garages.

Vertical enclosures which include structures, screens, and plants of different heights and varieties can be used to check intrusion into schools. Wire mesh fences, low railings, latticework, or stiff thorny plants may be used to keep children or dogs in or out of the school area without obstructing the view (Hickman, 2005). Some enclosures do not obscure the view. Among them are trellis or lattice frames, with or without glass or other fillers; rows of poles; louvered, split-wood, or other open-joint fences; and masonry provided with openings. Taller barriers of solid wood, masonry, or sheet materials are used to block both vision and movement. Enclosures may consist of wood, masonry, sheet materials, or vegetation. They may be of split, rough-sawn, or finished lumber; concrete block; brick; tile; stone; poured concrete; or stucco on a wood frame or on concrete block. They may be of sheet materials such as plywood, glass, plastics, or metal. Egan (2018) stated that trees and shrubs often make the best enclosures to checkmate intrusion to schools, particularly shrubs that grow erect and have little spread. If privacy cannot be obtained with plants, structural enclosures are used. During building designs, all these features may not be duly taken into consideration by the contractor which usually results to poor landscaping.

Ashworth (2004) relates that inadequate design and/or incorrect specification leads to poor landscaping. He also stated that most construction sites that run into trouble due to reasons related to managerial factors rather than because of technical problems. Egan, (2018), opined that cost is a critical factor in most building projects and some clients will seek a low price. Low price often have negative impacts on quality standards of school buildings as landscaping may be neglected in the entire building process of the school. Speedy completion is often required on commercial developments and the pressure to achieve early completion intensifies when financing and interest costs associated with acquiring the site begin to mount. Subsequently, Ecalle (2006) pointed out that the client's attitude towards initial versus the whole life cost of the building can significantly influence the specification. School 
buildings incur costs over their life time; these include initial capital costs, operating costs, and other maintenance costs. The key decision is whether to spend more money initially on better alternatives in order to save money in maintaining and operating the facility, thus most school owners prefer to neglect landscaping in order to reduce its maintenance cost over time. The location of the school project influence the nature of landscape in the area, as limited space for the school premises, staff accommodation facilities and material storage, may limit the proper landscaping of the school environment, (Lelket \& Ozel, 2003). The site topography i.e. the natural site features, ground conditions and obstructions, existing and adjoining building, underground and over-ground services all impact on how the building is designed and subsequently constructed. Poor landscaping have significant effects on pupil and teacher well-being as poor quality lighting, ventilation, acoustics and furniture all have a negative effect on student achievement and health.

Poor landscaping of public/private primary school can lead to heavy consequences and negative effects. Flooding and drainage issues can occur in the school environment as a result of poor landscaping. Claudio, Rivera, and Ramirez (2016) found that poor landscaping could result to sick building syndrome (SBS), which refers to building related sickness experienced by occupants when in a building or a specific part of the building. Diverse building related sickness such as headache, tiredness, fatigue, cough, itching and burning eyes, runny nose and their related causes have been identified in the literature. Claudio et al., (2016) found that dust was associated with colds, nasal congestion and sore throats, while carpets induce the risk of having asthma and itchy eyes. Also, the result of their study showed that respiratory infections, eye irritation, nasal congestion and sore throats were associated with damaged water system or mold. Ashworth (2004) stated that thieves, bandits and other unwanted element can intrude into the schooling environment due to poor landscaping of the school, poor choice of landscaping material and in most cases due to lack of landscaping of the school perimeter. Poor landscaping of school premises can affect the installation of building services (such as lighting, air conditioning, etc.) which are usually provided in learning spaces so as to improve comfort, health and safety of the occupants, and facilitate the learning process between the teachers and the students. Learning and other academic activities take place in an indoor environment, and lighting, ventilation, structural safety, temperature, sound control, fire safety and aesthetics are parameters whose failure, affects health and safety in an academic environment.

Schools generally are concerned with creating effective teaching and learning spaces for both teachers and learners. Sadly, school communities find themselves in situations where other concerns take up most of their energies with a result that the core business of schools although important, often becomes a secondary priority (Miller \&White, 2009). In particular, schools are faced with matters of safety and security breaches due to intrusion and numerous incidents have also been reported. Claudio et al.(2016) stressed that on many occasions, some unknown persons gained access to a public school in the suburb and the school lost a great number of school properties on each occasion which include; student's desks, laptops, refrigerator and generator sets which serves as alternative power supply for the school 
premises. Also, Xaba, (2006) reported that on many occasions some unknown persons have gained access to some private primary schools across the region. He stressed that these hoodlums carted away with the goods in the school canteen, ransacked and left with many of the desktop computers in the ICT/Computer Department of the schools respectively. Miller \& White (2009) suggests that schools are porous to attacks due to poor landscaping materials used on most school premises and also very poor landscaping network which fail to prevent the intrusion of hoodlums into the school premises. It is on the basis of these incidents that the researchers deemed it necessary to study the rationale for material selection in landscaping for checking intrusion in public and private primary schools in Nsukka Urban.

\section{Methodology and Procedures}

A descriptive survey research design was adopted for the study. It was conducted in Nsukka Urban area of Enugu State, Nigeria. The population of the study is102 subjects; comprising 82 teachers from five public/primary schools in Nsukka Urban and 20 builders practicing in Nsukka Urban area of Enugu State. Due to the manageable size of the population, there was no sampling as the entire population was used for the study. A 25 item questionnaire was developed from literature to obtain data for the study. A 4-point Likart scale was used to develop the questionnaire. The scale for the questionnaire was Strongly Agree (SA) - 4, Agree (A) - 3, Disagree (D) - 2 and Strongly Disagree (SD) - 1.

The questionnaire was face validated by three experts from the Faculty of Vocational and Technical Education, University of Nigeria, Nsukka. Their suggestions and recommendation were integrated into the final copy of the questionnaire. The questionnaire was administered to the 102 respondents. The data collected was analyzed using mean, standard deviation and t-test statistics. The mean and standard deviation were used to answer the research questions, while the Cranach alpha was used to determine internal consistency of the instrument, a reliability coefficient of 0.85 was obtained. Arithmetic mean of 2.5 was used to interpret the analysed data. An item with a mean of 2.5 and above was accepted, while items having their mean below 2.5 were rejected.

\section{Results and Discussion}

Research Question 1: What are the causes of poor Landscaping in public and private primary schools in Nsukka Urban?

Table 1:Mean ratings of the responses of respondents on the causes of poor Landscaping in public and private primary schools in Nsukka Urban.

\begin{tabular}{lllll}
\hline S/N & Item Statement & $\overline{\boldsymbol{x}}$ & SD & Remarks \\
\hline 1 & Contractor's improper planning, poor planning and scheduling & 3.21 & 0.92 & Accepted \\
2 & $\begin{array}{l}\text { Contractor's poor site management and supervision } \\
3\end{array}$ & 3.06 & 0.97 & Accepted \\
4 & $\begin{array}{l}\text { Inadequate contractor experience or incompetence of contractor } \\
\text { Resources shortage (human resources, machinery, equipment) }\end{array}$ & 3.0 & 0.94 & Accepted \\
& $\begin{array}{l}\text { and shortage of equipment and tools on site } \\
5\end{array}$ & 0.60 & Accepted \\
& $\begin{array}{l}\text { Mistakes during the construction stage or design changes during } \\
\text { construction stage. }\end{array}$ & 3.01 & 0.90 & Accepted \\
\hline
\end{tabular}




\begin{tabular}{lllll}
\hline 6 & Owners financial constraints/difficulties & 3.32 & 0.80 & Accepted \\
7 & $\begin{array}{l}\text { Shortages or inadequacies in industry infrastructure, and on } \\
\text { mainly supply of resources. }\end{array}$ & 2.79 & 0.96 & Accepted \\
8 & $\begin{array}{l}\text { The client's lack of experience in construction projects } \\
9\end{array}$ & 2.18 & 1.09 & Rejected \\
10 & Poor labour productivity and shortage of skills. & 2.91 & 0.81 & Accepted \\
$\bar{x}$ & Bad soil conditions, and bad weather of the site & 3.33 & 0.74 & Accepted \\
\hline
\end{tabular}

$\overline{\boldsymbol{x}}=$ Mean, $S D=$ Standard Deviation

Source: Authors

From Table 1, nine items had means above 2.5 showing that the respondents rejected only one item while they accepted the other nine items stated, as the causes of poor Landscaping in public and private primary schools in Nsukka Urban. This shows that the main causes of poor Landscaping in public and private primary schools includes; contractor's poor site management and supervision and inadequate contractor experience or incompetence of contractor. The SD ranged from 0.60-0.97 which showed that the respondents are not too far from each other in their responses.

Research Question 2: What are the effects of poor Landscaping in public and private primary schools in Nsukka Urban?

Table 2: Mean responses of the respondents on the effects of poor Landscaping in public and private primary schools in Nsukka Urban. $\mathbf{N}=\mathbf{1 0 2}$

\begin{tabular}{lllll}
\hline S/N & Item Statement & $\overline{\boldsymbol{x}}$ & SD & Remarks \\
\hline 11 & $\begin{array}{l}\text { Exposure of schools to risk of attacks and theft } \\
\text { Exposure of schools to ecological problems such as flooding, }\end{array}$ & 3.53 & 0.74 & Accepted \\
erosions, deep gullies and a degrading environment & 0.84 & Accepted \\
13 & $\begin{array}{l}\text { Exposure of school staff and students to social vices such armed } \\
\text { robbery attacks, kidnapping, raping and burglary etc. }\end{array}$ & 3.32 & 0.73 & Accepted \\
14 & $\begin{array}{l}\text { Staff and Student's poor performances in academic activities } \\
\text { due to divided attention over their safety and wellbeing in } \\
\text { school. }\end{array}$ & 0.41 & Accepted \\
$15 \quad \begin{array}{l}\text { Loss of lives and properties due to intrusion of bad elements } \\
\text { into the school environment. }\end{array}$ & 0.84 & Accepted \\
$16 \quad \begin{array}{l}\text { Emotional trauma and psychological pains associated with loss } \\
\text { of lives and properties due to intrusion into the school. }\end{array}$ & 0.50 & Accepted \\
\hline $\begin{array}{l}\mathbf{\mathbf { x }}=\text { Mean, SD =Standard Deviation } \\
\text { Source: Authors }\end{array}$ & & &
\end{tabular}

From Table 2, it shows that the respondents accepted all the six items as the effects of poor Landscaping in public and private primary schools. This shows that the effects of poor Landscaping in public and private primary schools include loss of lives and properties due to intrusion of bad elements into the school environment and staff and student's poor performances in academic activities due to divided attention over their safety and wellbeing in school. The SD ranged from 0.73-0.84 which showed that the respondents are not too far from each other in their responses.

Research Question 3: What are the criteria for materials selection for landscaping in checking intrusion in public and private primary schools in Nsukka Urban? 
Table 3: Mean responses of the respondents on the criteria for materials selection for landscaping in checking intrusion in public and private primary schools in Nsukka Urban.

\begin{tabular}{lllll}
\hline $\mathbf{S} / \mathbf{N}$ & Item Statement & $\overline{\boldsymbol{x}}$ & SD & Remarks \\
\hline $\mathbf{1 7}$ & $\begin{array}{l}\text { It is important to consider the durability, maintenance, and } \\
\text { aesthetic of each landscaping material }\end{array}$ & 0.97 & Accepted \\
$\mathbf{1 8}$ & $\begin{array}{l}\text { Initial and ongoing costs, and availability of the material to be } \\
\text { used }\end{array}$ & 3.66 & 0.92 & Accepted \\
$\mathbf{1 9}$ & $\begin{array}{l}\text { Materials should be selected for ignitability, surface spread of } \\
\text { flame, fire loading, and fire resistance and stability. } \\
\text { The impact of the disposal of materials at the end of their } 3.41\end{array}$ & 0.94 & Accepted \\
$\mathbf{2 0}$ & 0.92 & Accepted \\
$\mathbf{2 1}$ & $\begin{array}{l}\text { The life cycle assessment considerations such as material } \\
\text { performance, availability and impact on the environment and the } \\
\text { ability to reuse the material should be considered. }\end{array}$ & 0.96 & Accepted \\
$\mathbf{2 2}$ & $\begin{array}{l}\text { Materials usedshould be sustainable, meaning that the present } \\
\text { use will not compromise future use by running out or harming } \\
\text { the environment at any time. }\end{array}$ & 1.97 & Accepted \\
$\begin{array}{l}\text { The source of materials should be considered to keep transport } \\
\text { costs and resultant emissions to a minimum. } \\
\text { Cost considerations should include the initial cost of purchase } \\
\text { and Maintenance cost considerations of the materials }\end{array}$ & $\begin{array}{l}\text { Health and safety during construction/installation of the } \\
\text { materials should be considered. }\end{array}$ & 0.90 & Accepted \\
$\mathbf{2 5}$ & 0.81 & Accepted \\
\hline
\end{tabular}

$\overline{\boldsymbol{x}}=$ Mean, $S D=$ Standard Deviation

Source: Authors

From table 3, all the items were accepted showing that the respondents agree that all the items mentioned are the criteria for materials selection for landscaping in checking intrusion in public and private primary schools. They include; initial and ongoing costs, durability and availability of the material to be used and the source of materials should be considered to keep transport costs and resultant emissions to a minimum. The SD ranged from $0.81-1.02$ which showed that the respondents are not too far from each other in their responses.

\section{Discussion of Findings}

The findings from Table 1 indicate that the causes of poor Landscaping in public and private primary schools are contractor's improper planning, poor planning and scheduling, contractor's poor site management and supervision and Inadequate contractor experience or incompetence of contractor. The findings are supported by Ozdemir \& Yilmaz (2008) where they argued that mistakes of the contractor during the construction stage or design changes during construction stage affects the nature/form of landscaping in school environments. Also, the findings are also supported by Uwaifo, V.O. (2008) in which he revealed that bad soil conditions, bad weather of the site and shortages or inadequacies in industry infrastructure, mainly supply of resources can lead to poor landscaping of the school environment. 
The findings from Table 2 shows that the effects of poor Landscaping in public and private primary schools include exposure of schools to risk of attacks and theft, exposure of schools to ecological problems such as flooding, erosions, deep gullies and a degrading environment and staff and student's poor performances in academic activities due to divided attention over their safety and wellbeing in school. The findings is supported by Powl and Skitmore (2005) when they indicated that effects of poor landscaping in schools can lead to exposure of school staff and students to social vices such armed robbery attacks, kidnapping, raping and burglary etc, loss of lives and properties due to intrusion of bad elements into the school environment, the emotional trauma and psychological pains associated with loss of lives and properties due to intrusion into the school.

Finally, the findings from Table 3 indicate that the criteria for materials selection for landscaping in checking intrusion in public and private primary schools are initial and ongoing costs, durability and availability of the material to be used, the impact of the disposal of materials at the end of their serviceable life must be considered and the health and safety during construction/installation of the materials should be considered. This is supported by Chapman (2010) where he noted that the life cycle assessment considerations such as material performance, availability and impact on the environment and the ability to reuse the material should be considered while choosing a material for school landscaping. Also, Mohsini and Davidson (1992) backed up the findings when their study discovered that it is important to consider the durability, maintenance, aesthetic and cost of each landscaping material and also the cost considerations should include the initial cost of purchase and maintenance cost considerations of the materials for landscaping in checking intrusion for schools.

\section{Conclusion and Suggestion}

The basis of this study was to ascertain the rationale for material selection in landscaping for checking intrusion in public and private primary schools. Among the causes of poor landscaping in public and private primary schools is the contractor's improper planning, poor planning and scheduling and shortages or inadequacies in industry infrastructure, and on mainly supply of resources. Similarly, the study identified the effects of poor landscaping in public and private primary schools which include; exposure of schools to risk of attacks, theft and exposure of schools to ecological problems such as flooding, erosions, deep gullies and a degrading environment. Lastly, the study also identified; the durability, maintenance, aesthetic and cost of each landscaping material and the impact of the disposal of materials at the end of their serviceable life as the criteria for materials selection for landscaping in checking intrusion in public and private primary schools. It was evident from the findings of the study that certain threats to staff, students and school properties that existed in many schools will be reduced if not completely eliminated especially when appropriate landscaping practices are adopted.

Based on the findings, it is recommended that government at all levels should appoint task force team saddled with the responsibility of monitoring building contractors to ensure that 
proper landscaping are incorporated in their master plan and properly executed during school construction processes. It is suggested that government at all levels provide the necessary laws that will make school landscaping mandatory for all public/private schools. This will ensure that school landscaping is part of their master plan to help check intrusion into the school environment. In addition, the government, media outlets and the private sector should organize seminars, town hall meetings and conferences to enlighten the public on the need for adequate landscaping of the school premises in order to check for intrusion.

\section{Conflict of Interest}

The authors of the article declare no conflict of interest.

\section{Funding}

This research study was not funded by any institution. The authors conducted the study at their own expenses.

\section{Availability of Data and Material}

The data that support the findings of this study are available from the corresponding author, upon reasonable request.

\section{References}

Ashworth, A (2004). Cost Studies of Buildings, 4th ed. Pearson Education Ltd, Harlow Essex. Benjamin Nworie, (2018). Gunmen Attacks a primary School in Umuchigbo-Opi, Nsukka. Accessed from www.thisdaylive.com/index.php/2018 on 19th March, 2019.

Brook, M. (2016). Estimating and tendering for construction work. Taylor \& Francis.

Clamp, H, Cox, S and Lupton S, (2007) Which Contract? Choosing the Appropriate Building Contract, 4th ed. RIBA Publishing, London.

Clare Hickman, (2005). Therapatic Gardens: An Overview of the History Of Hospitals Gardens in England From 1800. UK, Bristol University, p. 8.

Claudio, L. Rivera, G.A., and Ramirez, O.F. (2016). Association between Markers of Classroom Environmental Conditions and Teachers' Respiratory Health. Journal of School Health, 86(6), 444-451. doi: https://doi.org/10.1111/josh.12398

Chapman, R.J., (2010). The likelihood and impact of changes of key project personnel on the design process. Construction Management and Economics, (17), 10-106.

Dudek, M., (2000). Architecture of schools: the new learning environment. Oxford; Boston: Architectural Press.

Egan J (2018).Rethinking Construction: The Report of the Construction Task Force to the Deputy Prime Minister, John Prescott, on the Scope for Improving the Quality and Efficiency of UK Construction, HMSO, London.

Ecalle, J., Magnan, A., \& Gibert, F. (2006). Class size effects on literacy skills and literacy interest in first grade: A large-scale investigation. Journal of school psychology, 44(3), 191-209. 
Garret, K, (2008). Learning through Landscapes; Learning Outside the Classroom. Winchester, Hampshire, UK.

Kirkham, R (2007).Ferry and Brandon's Cost Planning of Buildings, 8th ed. Blackwell Publishing, Oxford.

Kelkit, A., \& Ozel, A. E. (2003). A research on the determination of physical planning of school gardens in Çanakkale city. Journal of Applied Sciences, 3(4), 240-246.

Latham, M (1994) Constructing the Team: Final Report of the Government/Industry Review of Procurement and Contractual Arrangements in the UK Construction Industry, HMSO, London.

Mohsini, R.A., and Davidson, C.H., (1992). Determinants of performance in the traditional building process. Construction Management and Economics, (10), pp.343-359

Miller, D.; Tichotaand, K. \& White, J. (2009). Young Children Learn Through Authentic Play in a Nature Explore Classroom. Lincoln, Neb. Dimensions Foundation.

Obi, S. N., \& Ozumba, B. C. (2007). Factors associated with domestic violence in south-east Nigeria. Journal of obstetrics and gynaecology, 27(1), 75-78.

Ozdemir, A., \& Yilmaz, O. (2008). Assessment of outdoor school environments and physical activity in Ankara's primary schools. Journal of Environmental Psychology, 28(3), 287-300.

Pellegrini, A. D. (1995). School Recess and Playground Behavior: Educational and Developmental Roles. Albany: State University of New York Press. 187.

Powl A., Skitmore M., (2005). Related factors hindering the performance of construction project managers. Construction Innovation, (5), 41-51.

Seeley, I.H (1996).Building Economics, 4th ed. Macmillan, Basingstoke Hampshire.

Smith, J and Jagger, D (2007). Building Cost Planning for the Design Team, 2nd ed. Butterworth Heinemann, Oxford.

Tony Okafor. (2018). Gunmen Attacks School in Nsukka Community, accessed from www. Punchng.com/buharill-create/cxvp/2019 on 20 ${ }^{\text {th }}$ March, 2019.

Uwaifo, V.O. (2008). The Effects of Family Structure and Parenthood on the Academic Performance of Nigerian University Students. Global journal of Human Social Science. 2 (2):121-124.

Wargo, J. (2004). The World Health Organization's information series on school health: The physical school environment. New Haven Connecticut: Yale University.

Xaba, M. (2006).An investigation into the basic safety and security status of schools' physical environments. South African Journal of Education, 26(4), 565-580. 